Al-Huquq: Journal of Indonesian Islamic Economic Law, 3 (2), 2021: 143 - 162

ISSN: 2715-0003; E-ISSN 2714-5514

DOI: http://doi.org/10.19105/alhuquq.v3i2.5218

\title{
Hukum Bisnis Perspektif Islam dan Kapitalis (Tinjauan Teoritis Pada Aktivitas Bisnis di Indonesia)
}

\author{
Bhismoadi Tri Wahyu Faizal \\ (Fakultas Syariah IAIN Madura, Jl. Raya Panglegur Km. 4 Pamekasan 69371)
}

\begin{abstract}
Abstrak:
Sistem ekonomi merupakan sistem yang digunakan dalam sebuah negara untuk mengatur dan mengelola semua bentuk aktivitas ekonomi, sehingga dengan berlakunya sebuah sistem ekonmi ini, negara dapat memaksimalkan perannya dalam mengelola dan meningkatkan segala sumber daya yang dimiliki. Tulisan ini mencoba untuk membandingkan sebuah sistem ekonomi Islam dengan sistem ekonomi kapitalis yang keduanya memiliki perbedaan yang sangat mencolok ketika diaplikasikan dalam aktivitas bisnis. Hasil kajian menyimpulkan bahwa sistem ekonomi Islam mengemban visi homo Islamicus yang memandang manusia sebagai kholifah di muka bumi yang diberi kemampuan oleh Allah untuk mengelola bumi beserta isinya dengan baik dalam memenuhi kebutuhannya sendiri dan orang di sekitarnya dengan tujuan memberikan keseimbangan antara individu, masyarakat dan negara, sehingga pengaplikasiannya dalam aktivitas bisnis adalah economic value of time atau nilai ekonomi adalah waktu. Sedangkan sistem ekonomi kapitalis mengemban visi homo economicus yang memandang manusia sebagai makhluk ekonomi dengan sistem yang bertujuan untuk meraih keuntungan sebesar-besarnya dengan modal yang kecil, sehingga pengaplikasiannya dalam aktivitas bisnis adalah time value of money atau nilai waktu adalah uang. (An economic system is a system used in a country to organize and manage all forms of economic activity, so that with the enactment of an economic system, the state can maximize its role in managing and improving all resources at its disposal. This paper attempts to compare an Islamic economic system with a capitalist economic system, both of which have very striking differences when applied in business activities. The results of the study concluded that the Islamic economic system carries a vision of homo Islamicus who views humans as kholifah on earth who is given the ability by Allah to manage the earth and its contents
\end{abstract}

email koresproden wahyu@iainmadura.ac.id

https://creativecommons.org/licenses/by-nc/4.0/

Copyright (c) 2019 by al-huquq. All Right Reserved 
well in meeting its own needs and those around it with the aim of providing balance between individuals, communities and the state, so that its application in business activities is economic value of time or economic value is time. While the capitalist economic system carries a homo economicus vision that views humans as economic creatures with a system that aims to achieve maximum profits with small capital, so that its application in business activities is time value of money or time value is money).

Kata Kunci:

Hukum Bisnis, Islam dan Kapitalis, Aktivitas Bisnis

\section{Pendahuluan}

Aktivitas bisnis bukanlah suatu hal yang baru dalam dinamika sosial kehidupan masyarakat Indonesia. Jauh sebelum Indonesia merdeka pada tahun 1945, aktivitas bisnis telah dilakukan oleh banyak orang di Nusantara maupun di dunia. Dalam khazanah Islam, aktivitas bisnis telah dicontohkan langsung oleh baginda Nabi Muammad SAW., sebagaiman tercacat dalam sejarah bahwa Nabi Muhammad SAW., adalah seorang pedagang terhitung sejak beliau sering mengikuti pamannya untuk berdagang dalam usianya yang tergolong muda yaitu pada usia 9 Tahun.

Sejarah juga mencatat aktivitas bisnis di Indonesia telah berlangsung bahkan sejak sebelum tentara kolonial menjajah Indonesia. Aktivitas bisnis di Inodonesia sudah ada sejak zaman kerajaan-kerajaan besar yang pernah berdiri di Nusantara, salah satunya yang termasyhur dan tersohor adalah kerajaan Majapahit yang terletak di pulau Jawa bagian timur. Hal ini terbukti karena terdapat pengaruh yang signifikan dari sistem perdagangan terhadap pencapaian puncak kejayaan kerajaan Majapahit kala itu, perdagangan yang ada dalam kerajaan tersebut pun bukan hanya perdagangan antar daerah saja, namun sudah berskala internasional. ${ }^{1}$

Kilas balik rekam sejarah bangsa Indonesia pra kemerdekaan tentu perlu untuk kita lakukan ketika berbicara mengenai segala aktivitas bisnis di Indonesia. Sebab secara garis keturunan, negara

1 Adrian Perkasa, Orang-Orang Tionghoa Dan Islam Di Majapahit (Yogyakarta: Ombak, 2012), 31. 
Hukum Bisnis Perspektif Islam dan Kapitalis

(Tinjauan Teoritis Pada Aktivitas Bisnis di Indonesia)

Indonesia diwarisi sifat-sifat positif oleh leluhurnya, yaitu sebuah bakat dan kemampuan mengelola negara bangsa dengan baik, tidak terkecuali di bidang ekonomi. Sejarah membuktikan bahwa di Indonesia pernah berdiri negara bangsa yang besar, diantaranya adalah Kerajaan Tarumanegara, Kerajaan Sriwijaya, dan yang paling tersohor adalah Kerajaan Majapahit. ${ }^{2}$

Sepanjang sejarah peradaban manusia, setidaknya terdapat beberapa sistem ekonomi yang pernah populer, yaitu sistem ekonomi despotisme, kapitalisme, dan sosialisme. ${ }^{3}$ Sistem ekonomi despotisme adalah bentuk dari sistem ekonomi yang tergolong paling primitif yang diatur oleh otoritas tunggal perseorangan atau sekelompok orang yang memimpin. Akan tetapi sistem ekonmi ini tidak bertahan begitu lama, sebab tidak sanggup merespon permasalahan manusia yang semakin komplek, sehinnga sistem ekonomi ini ditinggalkan oleh para penganutnya.

Pasca runtuhnya sistem ekonomi despotisme, muncullah kemudian sistem ekonomi sosialis dan sistem ekonomi kapitalis. Namun kehadiran sistem ekonomi kapitalisme di Indonesia belum dikatakan mampu mengatasi segala problematika yang ada. Sebaliknya malah menjerumuskan warga Indonesia pada lubang kesengsaraan yang tak kunjung teratasi. Hal ini dapat dibuktikan dengan krisis moniter yang menimpa warga Indonesia pada tahun 1997-1998 silam.

Fakta di atas yang mendorong para pemikir dan cendikiawan muslim untuk melihat kembali warisan Islam guna mencari jawaban atas persoalan maupun untuk membudidayakan sistem ekonomi yang lebih mendukung aktivitas bisnis berdasarkan prinsip-prinsip Islam. Hal ini juga didorong oleh kesadaran sebagian besar umat Islam di Indonesia akan pentingnya sebuah sistem ekonomi bisnis yang dapat menjadi maslahat bagi orang lain serta mendapat keuntungan ganda yaitu di dunia dan di akhirat kelak.

\footnotetext{
${ }^{2}$ Irham Rosdyidi, "Reaktualisasi Model Formulasi Norma Hukum Berbasis Asas Kejujuran Konstitusi Kerajaan-Kerajaan Di Nusantara Ke Dalam Undang-Undang Dasar Negara Republik Indonesia Tahun 1945 (Kerajaan Pagarruyung, Kasunanan Surakarta, Kerajaan Bone, Dan Kesultanan Tidore)" (Universitas Brawijaya, 2015), 1, http://repository.ub.ac.id/id/eprint/160416.

${ }^{3}$ Muhammad Ghozali and Yusi Septa Prasetya, "Ribā Dan Ketidakadilan Sistem Ekonomi Kapitalisme, Sebuah Kajian Teoritis," Islamic Economics Journal 3, no. 1 (2017): 472-93, https://doi.org/10.21111/iej.v3i1.1385.
} 


\section{Metode Penelitian}

Jenis penelitian ini adalah penelitian hukum normatif dengan menggunakan pendekatan perbandingan (comparative approach) yang berusaha membandingkan dua sistem ekonomi terkemuka di dunia yakni sistem ekonomi Islam dan sistem ekonomi Kapitalis dan pengaplikasiannya dalam aktivitas bisnis di Indonesia. Jenis penelitian hukum normatif bertumpu pada sumber data sekunder yang terdiri dari bahan hukum primer, bahan hukum sekunder dan bahan hukum tersier, kemudian dianalisis secara deskriptif analitik untuk kemudian disimpulkan dengan metode deduktif.

\section{Aktivitas Bisnis Perspektif Islam}

Aktivitas bisnis Islam merupakan aktivitas bisnis yang didasarkan pada sistem ekonomi tertua jika dibandingkan dengan sistem ekonomi konvensional yang terdiri dari sistem ekonomi kapitalis dan sosialis. Sistem ekonomi sebagaimana dimaksud di atas adalah sistem ekonomi Islam atau yang saat ini populer dengan sebutan sistem ekonomi syariah yang keberadaannya telah muncul sejak abad ke-6, berbeda dengan sistem ekonomi kapitalis baru berjalan pada abad ke-17 kemudian disusul setelah itu sistem ekonomi sosialis pada abad ke-18. ${ }^{4}$

Selain itu, Euis Amalia juga menerangkan bahwa aktivitas bisnis Islam telah dipraktikkan langsung oleh baginda Nabi Muhammad Saw., bersama dengan beliau para pedagang Makkah dan Madinah pada tahun 569-632 M. Setelah periode baginda Nabi Muhammad Saw., dilanjutkan oleh periode al-Khulafa al-Rasyidin yang membangun pemerintahan selama 29 tahun, yaitu pada tahun 632-661 M. Namun aktivitas bisnis Islam tidak berhenti setelah periode alKhulafa al-Rasyidin saja, namun aktivitas bisnsi Islam terus berlanjut hingga kejayaan Islam di Turki. ${ }^{5}$

Menurut Yahya ibnu Umar sebagaimana dikutip oleh Adiwarman Azwar Karim, aktivitas ekonomi merupakan sebuah komponen yang tidak dapat dipisahkan dengan ketakwaan seorang hamba kepada Allah Swt. Artinya, ketakwaan berarti sebuah asaz dalam sistem ekonomi Islam yang akan disandang oleh seseorang yang

\footnotetext{
${ }^{4}$ Novita Lidyana, "Perbandingan Ekonomi Konvensional Dan Ekonomi Islam," n.d.

${ }^{5}$ Euis Amalia, Sejarah Pemikiran Ekonomi Islam Dari Masa Klasik Hingga Kontemporer (Jakarta: Pustaka Asatrus, 2005), 16-61.
} 
melakukan aktivitas bisnis berdasarkan pada prinsip-prinsip Islam. Hal ini juga dapat dijadikan pembeda antara sistem ekonomi Islam dan sistem ekonomi kapitalis. ${ }^{6}$

Mengenai landasan atau prinsip yang harus dipegang teguh dalam aktivitas bisnis Islam menurut Abdain setidaknya terdiri dari empat komponen, yaitu tauhid, adil, khilafah, dan tazkiyah. Keempat prinsip ini secara rinci akan diuraikan sebagai berikut; ${ }^{7}$

\section{Prinsip Kesatuan atau Ketuhanan (Tauhid)}

Tauhid bermakna kemahaesaan Allah Swt., sebagai sang maha pencipta, pemilik semua yang ada di bumi dan di langit, pemberi rizki yang adil, dan maha segala. Dalam ekonomi Islam, segala macam jenis sumber daya yang ada di alam semesta ini adalah milik Allah Swt., semata yang hanya diamanatkan kepada manusia untuk mengelola seoptimal mungkin dan dapat bermanfaat bagi manusia lain yang lebih membutuhkan, dan yang terpenting adalah bahwa segala bentuk kegiatan sebagaimana dimaksud di atas akan dipertanggungjawabkan di akhirat kelak. Dari sini dapat dipahami bahwa segala harta kekayaan tidak sepenuhnya menjadi milik manusia, melainkan milik Allah Swt., oleh karena itu, harta kekayaan yang hanya menumpuk pada satu orang saja harus disalurkan kembali kepada orang-orang yang membutuhkan, agar tidak terjadi kesenjangan sosial dalam sektor ekonomi, yang terpenting adalah menyalurkan sebagian harta yang dimiliki seseorang kepada orang yang membutuhkan adalah ibadah bahkan diwajibkan zakatnya jika harta itu sudah mencapai nisab.

\section{Prinsip Khalifah}

Manusia adalah sebagai khalifah (wakil Tuhan) di muka bumi yang harus menjalankan aturan-aturan dan hukum-hukum dari Allah Swt., posisi manusia sebagai khlifah dapat dilihat

\footnotetext{
${ }^{6}$ Adiwarman Azwar Karim, Sejarah Pemikiran Ekonomi Islam, 3rd ed. (Jakarta: Rajawali Press, 2004), 264.

${ }^{7}$ Abdain, "Peran Sistem Ekonomi Islam Dalam Menanggulangi Tingkat Kesenjangan Sosial," Jurnal Muamalah IV, no. 2 (2014): 16-18.
} 
dalam beberapa ayat dalam al-Qur'an, seperti dalam surat alBaqarah ayat 30 .

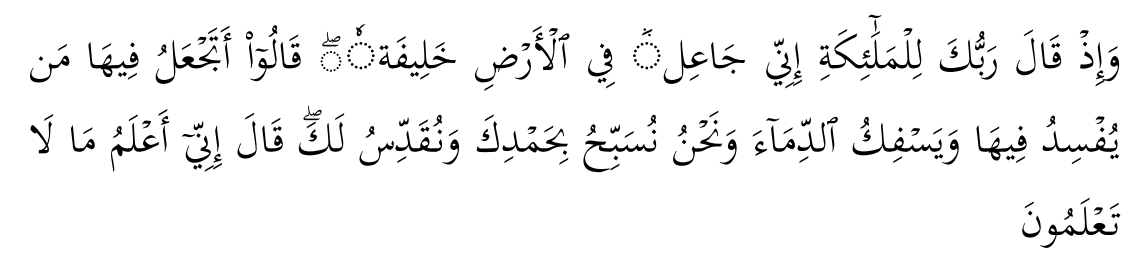

Ingatlah ketika Tuhanmu berfirman kepada para Malaikat: "Sesungguhnya Aku hendak menjadikan seorang khalifah di muka bumi". Mereka berkata: "Mengapa Engkau hendak menjadikan (khalifah) di bumi itu orang yang akan membuat kerusakan padanya dan menumpahkan darah, padahal kami senantiasa bertasbih dengan memuji Engkau dan mensucikan Engkau?" Tuhan berfirman: "Sesungguhnya Aku mengetahui apa yang tidak kamu ketahui"8

Sebagai kholifah, manusia diberi amanah oleh Allah Swt., untuk mengelola bumi dan isinya serta memanfaatkannya sebaik mungkin untuk kesejahteraan bersama. ${ }^{9}$ Menurut Umer Chapra sebagaimana dikutip oleh Abdai menyatakan bahwa prinsip khalifah dalam aktivitas bisnis Islam berimplikasi pada terjadinya persaudaraan universal, sumber-sumber daya adalah amanat, dan gaya hidup yang sederhana.

\section{Prinsip Keadilan}

Keadilan dalam ekonomi menduduki peranan yang sangat penting, berlaku dalam ekonomi tidak hanya diatur dalam alQur'an dan Sunnah, namun juga berlaku bagi hukum alam, hal ini dapat dilihat bahwa alam diciptakan berdasarkan pada prinsip keadilan dan keseimbangan. Berlaku dalam adil dalam berbisnis dapat diterapkan dalam penentuan harga, kualitas produk, perlakuan yang baik dan adil terhadap pekerja dan menghormati para konsumen.

\footnotetext{
${ }^{8}$ QS. Al-Baqarah (2):30

${ }^{9}$ Fadllan -, "Paradigma Madzhab-Madzhab Ekonomi Islam Dalam Merespon Sistem Ekonomi Konvensional," AL-IHKAM: Jurnal Hukum \& Pranata Sosial 7, no. 1 (2013): 164, https://doi.org/10.19105/al-lhkam.v7i1.322.
} 
Hukum Bisnis Perspektif Islam dan Kapitalis

(Tinjauan Teoritis Pada Aktivitas Bisnis di Indonesia)

\section{Prinsip Keseimbangan (tawazun)}

Kegiatan ekonomi harus didasarkan pada prinsip keseimbangan. Prinsip keseimbangan sebagaimana dimaksud adalah keseimbangan antara kebutuhan individu dan kebutuhan masyarakat umum. Jadi keseimbangan yang dimaksud disini bukan keseimbangan yang berkaitan antara kebutuhan duniawi dan ukhrowi saja. Kesejahteraan antar sesama umat manusia menjadi tujuan utama dalam aktivitas bisnis Islam, sehingga keseimbangan antara kebutuhan perseorangan dengan hajat orang banyak haruslah seimbang. ${ }^{10}$

Adapun karakteristik sistem ekonomi Islam menurut Sayyid Mahmud Teleghani dalam Chapra adalah sebagai berikut; ${ }^{11}$

\section{Hak Milik Harta}

Manusia sebagai kholifah Allah Swt., di muka bumi diamanhi oleh-Nya untuk mengelola bumi dengan hak milik yang terbatas dan bersyarat. Pembatasan tersebut diatur menurut tiga tingkatan yakni; a). Melalui keimanan dan hati nurani seseorang, b). Melalui aturan hukum dan, c). Melalui campur tangan pemerintah.

2. Pengambilan Keputusan dan Alokasi Sumber: Peranan Negara

Negara diamanahi untuk menjamin bahwa keadilan berlangsung di semua bidang kehidupan. Hal ini dilakukan negara dengan memikul tanggung jawab sebagai wali atau penyedia kesejahteraan publik. Dalam hal ini negara memiliki peranan penting dalam mengupayakan sebuah kesejahteraan bagi masyarakat melalui aktivitas bisnis yang berjalan di masyarakat.

3. Pelarangan Riba dan Implementasi Zakat

Dalam aktivitas bisnis Islam, tidak ada kompromi atas kebolehan pelaku bisnis untuk menerapkan sistem riba, karena

\footnotetext{
10 M. Umer Chapra, Islam Dan Tantangan Ekonomi: Islamisasi Ekonomi Kontemporer (Surabaya: Risalah Gusti, 1999), 1.

11 Mohamed Aslam Haneef, Pemikiran Ekonomi Islam Kontemporer: Analisis Komparatif Terpilih, ed. Suherman Rosyidi (Jakarta: Rajawali Press, 2010), 117-23.
} 
riba jelas dilarang dalam al-Qur'an dan as-Sunnah. Zakat merupakan jalan yang patut dilakukan oleh para pelaku bisnis, karena selain sebagai kewajiban agama, zakat juga dapat dimanfaatkan sebagai alat untuk memelihara kerja sama, distribusi yang adil dan untuk memenuhi permintaan publik.

Dari pemaparan di atas, maka dapat ditarik benang merah bahwa aktivitas bisnis perspektif Islam merupakan aktivitas bisnis yang mengacu kepada sistem ekonomi Islam, yaitu sebuah sistem ekonomi yang didasarkan pada prinsip-prinsip syariah sebagaimana telah disebutkan di atas.

Pada prinsipnya, sistem ekonomi Islam mengemban visi Homo Islamicus yaitu bagian besar dari Islam agar diresapi masyarakat. Dengan artian, manusia merupakan makhluk Allah Swt., yang paling sempurna di antara makhluk Allah Swt., yang lain, keberadaannya di muka bumi sebagai kholifah yang berperan untuk menggunakan segala potensi yang dimilikinya dalam mengelola bumi dan isinya hanya untuk kebaikan dirinya dan yang lebih utama untuk kesejahteraan masyarakat.

Konsep Homo Islamicus berawal dari pandangan Islam terhadap manusia. Manusia dipandang sebagai makhluk yang tidak hanya memiliki tubuh saja, namun juga dilengkapi dengan akal dan jiwa, sehingga manusia dipandang mampu mengelola bumi sebaik mungkin termasuk dalam sektor ekonomi. ${ }^{12}$ Berangkat dari visi ekonomi Islam yang terkonsep dalam Homo Islamicus inilah, maka lahirlah sebuah sistem ekonomi Islam yang memberikan keseimbangan antara peran individu, masyarakat dan negara. Maka dalam pengaplikasiannya, sistem ekonomi Islam lebih cenderung pada Economic Value of Money, yaitu nilai ekonomi adalah waktu.

\section{Aktivitas Bisnis Perspektif Kapitalis}

Kapitalisme bukanlah suatu istilah baru dalam kalangan pegiat hukum ekonomi dan bisnis di era modern ini. Secara etimilogi kata kapitalisme berasal dari bahasa Inggris yaitu capital yang berarti adalah modal atau suatu modal untuk ditanamkan. ${ }^{13}$ Adapun

12 Parmujianto, "Manajemen Sumber Daya Manusia Dan Mutu Modal Manusia Dalam Perspektif Ekonom Islam,” Et-Tijarie 4, no. 1 (2017): 110.

13 John M. Echols dan Hassan Shadily, Kamus Inggris Indonesia "An Engslish-Indonesian Dictionary" (Jakarta: Gramedia, 2005), 97. 
kapitalisme berarti seseorang yang memiliki modal. Dalam hal ini modal menempati posisi yang sangat strategis, karena modal dapat menentukan arah perekonomian dapat berlangsung atau justru mengalami "kemandegkan". ${ }^{14}$ Berangkat dari pemaparan di atas, dapat dipahami jika kapitalisme merupakan suatu sistem perekonomian yang bertumpu pada kekuatan modal untuk dapat memperoleh keuntungan yang sebesar-besarnya. ${ }^{15}$

Seperti yang telah disinggung di atas, bahwa modal menempati posisi yang sangat strategis dalam geliat bisnis maupun dalam menunjang ekonomi seseorang. Dengan posisi modal yang demikian, maka tidak mengherankan jika para pelaku usaha dengan modal yang besar dapat mengendalikan laju perekonomian di pasar bahkan dapat menguasai pasar untuk mendapatkan keuntungan sebesar-besarnya. ${ }^{16}$ Fernald Braudel pernah menyatakan bahwa "kaum kapitalis merupakan spekulator dan pemegang monopoli yang berada dalam posisi untuk memperoleh keuntungan besar tanpa menanggung banyak risiko". ${ }^{17}$

Istilah kapitalisme dalam Collins Dictionary digambarkan terhadap sebuah sistem ekonomi di mana alat-alat produksi, distribusi, ataupun pertukaran dimiliki atau dikuasi oleh pribadi atau swasta. Artinya, pihak-pihak selain pemilik modal produksi dan distribusi tidak memiliki andil dalam turut serta mengatur aktivitas bisnis yang dilakukan oleh pribadi atau swasta. Hal di atas berpengaruh pada profit motive sebagai pendorong utama semua usaha produktif sampai pada mekanisme harga yang menentukan sesuatu yang akan diproduksi, jumlahnya serta dalam kondisi yang bagaimana. ${ }^{18}$

Sehubungan dengan hal di atas, maka modal yang dikuasai oleh pribadi maupun swasta dalam sistem ekonomi kapitalis dapat dengan

\footnotetext{
${ }^{14}$ Pius A. Partanto dan M. Dahlan Al-Barry, Kamus Ilmiah Populer, ed. Arkola (Surabaya, 1994), 304.

${ }^{15}$ Rosyidin, "Aktivitas Bisnis Perspektif Islam Dan Kapitalis (Analisa Komparatif Terhadap Aspek Fundamental Ekonomi Islam Dan Kapitalis Dalam Aktivitas Bisnis)," At-Tahdzib 1, no. 2 (2013): 246.

${ }^{16}$ Choirul Huda, "EKONOMI ISLAM DAN KAPITALISME (Merunut Benih Kapitalisme Dalam Ekonomi Islam)," Economica: Jurnal Ekonomi Islam 7, no. 1 (2016): 29, https://doi.org/10.21580/economica.2016.7.1.1031.

17 Yhosihara Kunio, Kapitalisme Semu Asia Tenggara (Jakarta: LP3ES, 1990), 3.

18 Muhammad Sharif Chaudry, Sistem Ekonomi Islam: Prinsip Dasar (Jakarta: Kencana, 2012), 355 .
} 
bebas dimanfaatkan oleh penguasanya dalam membengkakkan laba terhadap usaha yang dijalankan. Tidak hanya modal, namun faktor produksi dan perdagangan juga dijalankan atas dasar prinsip yang individualistis karena kerajaan bisnis yang dibangun adalah untuk diri mereka sendiri dengan mengupah orang lain untuk bekerja. ${ }^{19}$

Terdapat banyak istilah yang termaktub dalam beberapa literatur terkait sistem ekonomi kapitalisme, ${ }^{20}$ di antaranya ada yang menyebutnya dengan ekonomi klasik yang bertumpu pada pandangan filsafat ekonomi klasik, ${ }^{21}$ sebagian ada yang menyebutnya dengan ekonomi yang diatur oleh tangan yang tak terlihat (invisible hand), sebagian ada yang menyebutnya ekonomi laissez-faire yaitu sikap pembiaran atas kebebasan tanpa pengaturan maupun kontrol, ${ }^{22}$ ada pula yang menyebutnya ekonomi pertukaran bebas berusaha, ekonomi dengan terbatasnya peran pemerintah sampai pada penyebutan ekonomi individualisme

Sistem ekonomi kapitalis sejatinya memiliki tujuan untuk merubah tatanan perekonomian dunia guna mencapai kemakmuran rakyat secara global. Dasar pemikiran ini dilatar belakangi oleh pandangan bahwa kesuksesan ekonomi akan dapat membawa seseorang pada kekayaan universal bahkan sampai pada lapisan masyarakat terendah jika dilakukan tanpa adanya campur tangan dari pihak lain yakni pemerintah. Dengan artian, setiap individu diberi kebebasan dalam mengelola dan mengembangkan modalnya untuk dapat terlibat dalam persaingan usaha yang bebas tanpa ada campur tangan pemerintah, sehingga setiap individu dapat dengan bebas melakukan tindakan ekonomi yang dikehendakinya. ${ }^{23}$

Adam Smith sebagai tokoh yang dikenal dengan sebutan Bapak Kapitalisme seperti yang dikutip oleh Choirul Huda menerangkan lima

\footnotetext{
${ }^{19}$ Muhammad Sharif Chaudry, 356.

${ }^{20}$ Suharyono dan Niam Sovie, Sistem Ekonomi Indonesia (Banten: Universitas Terbuka, 2014), 23.

${ }^{21}$ Mahsun Fuad, Hukum Islam Indonesia: Dari Nalar Partisipatoris Hingga Emansipatoris (Yogyakarta: Pelangi Aksara, 2005), 130-31.

${ }^{22}$ Huda, "EKONOMI ISLAM DAN KAPITALISME (Merunut Benih Kapitalisme Dalam Ekonomi Islam)," 33.

${ }^{23}$ Rosyidin, "Aktivitas Bisnis Perspektif Islam Dan Kapitalis (Analisa Komparatif Terhadap Aspek Fundamental Ekonomi Islam Dan Kapitalis Dalam Aktivitas Bisnis),” 19; Suharyono dan Niam Sovie, Sistem Ekonomi Indonesia, 2-3.
} 
teori dasar kapitalisme yaitu ${ }^{24}$ "pengakuan hak milik pribadi tanpa adanya batas tertentu, pengakuan hak milik pribadi untuk melakukan kegiatan ekonomi untuk meningkatkan status sosial ekonomi, pengakuan adanya motivasi ekonomi dalam bentuk semangat meraih keuntungan semaksimal mungkin, kebebasan melakukan kompetisi, mengakui hukum ekonomi pasar bebas/mekanisme pasar"

Ayn Rand dalam Choirul Huda berpendapat bahwa "Kapitalisme adalah a social system based on the recognition of individual rights, in which all property is privately owned (suatu sistem sosial yang berbasiskan pada pengakuan atas hak-hak individu, termasuk hak milik di mana semua pemilikan adalah hak milik privat)" ${ }^{25}$

Selain itu, Rand juga berasumsi bahwa kapitalisme berdiri di atas tiga pilar utama, yaitu kebebasan individu, kepentingan diri sendiri, dan mekanisme pasar bebas. Menurutnya, pilar pertama yaitu kebebasan individu menjadi pilar utama dan terpenting dalam tegaknya sistem ekonomi kapitalis yang memberikan pengakuan terkait dengan hak alami atas individu untuk bebas berpikir, berkarya dan terus berproduksi guna menyambung hidup dan meningkatkan level status sosial ekonominya. ${ }^{26}$

Paham terkait dengan hak individu yang dikembangkan oleh Rand di atas dimungkinkan bahwa setiap individu akan dapat memenuhi segala kepentingannya. Lebih tegas Rand menjelaskan bahwa "manusia hidup pertama-tama untuk dirinya sendiri, bukan untuk kepentingan dirinya". Paham ini kemudian dipengaruhi oleh gagasan the invisible hand yang dikembangkan oleh Smith, sehingga menambah keyakinan Rand bahwa pasar bebas akan selalu berkembang dan akan selalu menuntut yang terbaik. ${ }^{27}$

Sistem ekonomi kapitalis memiliki ciri khas yang dapat membedakannya sistem ekonomi lainnya terutama dengan sistem ekonomi Islam. Di antara ciri-cirinya yaitu memberikan jaminan penuh atas hak milik perseorangan, mementingkan diri sendiri, pemberian

\footnotetext{
${ }^{24}$ Huda, "EKONOMI ISLAM DAN KAPITALISME (Merunut Benih Kapitalisme Dalam Ekonomi Islam)," 36.

${ }^{25}$ Huda, 36.

${ }^{26}$ Huda, 36.

${ }^{27}$ Huda, 36.
} 
kebebasan penuh, persaingan bebas, harga sebagai penentu, dan minimnya peran negara. ${ }^{28}$

Ciri pertama dalam sistem ekonomi kapitalis adalah memberikan jaminan atau pengakuan penuh atas hak milik perseorangan. Dalam sistem ekonomi kapitalis, hak milik perseorangan atau pribadi menjadi bagian yang sangat penting, setiap individu mempunyai hak untuk melakukan penimbunan atas harta kekayaan yang dikuasainya tanpa memikirkan bagaimana keadaan orang-orang yang tidak bernasib sama di sekitarnya.

Tidak hanya itu, penganut sistem ekonomi kapitalis juga memiliki kecenderungan untuk mementingkan dirinya sendiri. Hal ini tentunya didasarkan karena sistem ekonomi kapitalis lebih menekankan gaya hidup individualisme. Oleh karenanya, setiap individu diberi kebebasan untuk berkembang dan melakukan setiap aktivitas sosial hanya untuk memenuhi kepentingannya sendiri. Menurut Adam Smith dalam Rustam Dahlan, mendahulukan kepentingan diri sendiri ini merupakan suatu wujud kekuatan untuk mengendalikan perekonomian ke arah kemakmuran bangsa. ${ }^{29}$

Secara filosofis, sistem ekonomi kapitalis bertumpu pada paham liberalisme yang memberikan kebebasan penuh kepada setiap individu untuk bertindak dan melakukan aktivitas ekonomi tanpa ada campur tangan dari negara (pemerintah). Dalam hal ini, pemerintah hanya difungsikan sebagai penyedia fasilitas dan pengatur lalu lintah yang diharapkan dapat mendorong setiap orang untuk melakukan kegiatan ekonomi. Kepercayaan kaum kapitalis menciptakan stigma bahwa setiap orang yang mendapati kepuasannya dalam aktivitas bisnis, maka kemakmuran masyarakt akan tercipta.

Adanya persaingan yang bebas juga menjadi salah satu ciri dari sistem ekonomi kapitalis. Yang dimaksud dengan persaingan bebas di sini adalah persaingan yang terjadi antara penjual dan pembeli atau konsumen dalam menawarkan kualitas terbaik kepada konsumen dan persaingan konsumen dalam menentukan harga terbaik bagi produsen. Penentuan harga juga menjadi hal penting. Artinya, mekanisme pasar yang menjadi penentu atas keseimbangan penawaran dan permintaan

\footnotetext{
${ }^{28}$ Ai Siti Farida, Sistem Ekonomi Indonesia (Bandung: Pustaka Setia, 2011).

${ }^{29}$ Rustam Dahlan, "Teori Invisible Hand Adam Smith Dalam Perspektif Ekonomi Islam," Jurnal Ekonomi 1, no. 1 (2010): 17.
} 
barang tidak boleh dicampuri oleh negara. Bahkan jika terjadi lonjakan atau kemerosotan harga akibat dari tidak seimbangnya penawaran dan permintaan barang atau jasa, negara masih dituntut untuk diam, karena penentuan harga oleh mekanisme pasar akan dapat menentukan keseimbangan dan harga baru atas segala ketidak seimbangan yang telah terjadi.

Tidak kalah pentingnya dalam menggambarkan ciri dari sistem ekonomi kapitalis adalah minimnya peran negara dalam memberikan kebijakan-kebijakan di bidang ekonomi. Sebagaimana telah disinggung sebelumnya bahwa peran negara hanya difungsikan sebagai penyedia fasilitas di bidang ekonomi seperti mengeluarkan mata uang, mengatur lalu lintas keamanan dan ketertiban, memberi ketetapan atas hak kekayaan pribadi, dan menjaga persaingan tanpa hambatan yang dapat menunjang laju perkembangan individu dalam melakukan kegiatan ekonomi.

Penting diketahui bahwa sistem ekonomi kapitalisme berkembang di Indonesia karena dipengaruhi oleh penjajahan yang dilakukan oleh tentara kolonial Belanda yang menjajah Indonesia selama 350 tahun. Lamanya penjajahan tersebut tentu akan berimbas pada matangnya perkembangan sistem ekonomi kapitalism di Indonesia.

Dari hasil pemaparan di atas maka dapat dipahami bahwa aktivitas bisnis yang didasarkan pada sistem ekonomi kapitalis merupakan sebuah aktivitas bisnis yang tergolong serakah karena jiwa dari sistem ekonomi kapitalis sangat jelas lebih mengedepankan rasa egoisme, bebas menumpuk harta kekayaan, dan bebas membelanjakannya tanpa memperhatikan kepentingan orang lain kecuali jika terdapat keuntungan yang dapat dipetiknya.

Maka dapat disimpulkan bawa sistem ekonomi kapitalis mengemban visi Homo Economicus, yaitu mendapatkan keuntungan yang sebesarnya-besarnya dengan modal yang sedikit. Dalam teori ekonomi konvensional ini, manusia dipandang sebagai makhluk ekonomi (homo economicus) yang mementingkan dirinya sendiri. ${ }^{30}$ Pemaparan di atas jelas menunjukkan bahwa sistem ekonomi kapitalis

\footnotetext{
30 Parmujianto, "Manajemen Sumber Daya Manusia Dan Mutu Modal Manusia Dalam Perspektif Ekonom Islam,” 109.
} 
lebih menekankan kebebasan individu tanpa harus memperhatikan kepentingan masyarakat umum dan peran negara, sehingga dalam pengaplikasiannya, sistem ekonomi kapitalis cenderung kepada Time Value of Money, yaitu nilai waktu adalah uang.

\section{Perbandingan Aktivitas Bisnis Perspektif Islam dan Kapitalis}

Menurut Parmujianto, salah satu kekeliruan fundamental dalam teori ekonomi konvensional adalah pandangannya terhadap manusia yang dianggap sebagai makhluk ekonomi (homo economicus) yang mementingkan dirinya sendiri tanpa memperhatikan kepentingan orang lain. Islam tidak memandang manusia serendah pandangan teori ekonomi konvensional. Melainkan, Islam memandang manusia sebagai makhluk termulia, sehingga dalam pengelolaannya pun tidak merendahkan derajatnya sebagai makhluk Tuhan yang paling mulia di antara makhluk-makhluk yang lain. Dalam Islam, manusia adalah kholifah (homo Islamicus), hal ini sesuai dengan firman Allah Swt., dalam Surah as-Sajadah (32): 9;

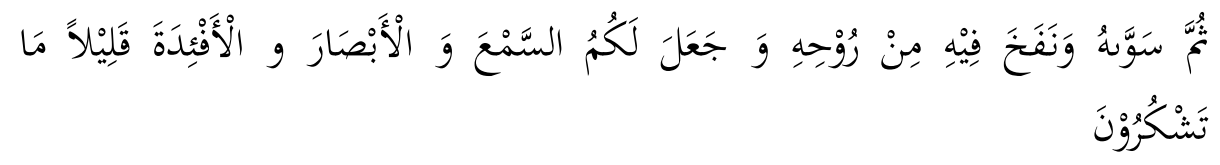

Artinya: Kemudian, Ia sempurnakan kejadiannya, dan Ia tiupkan kepadanya sebagian dari ruh-Nya dan Ia jadikan bagi kamu pendengaran dan penghlihatan dan hati, tetapi sedikit sekali kamu bersyukur. ${ }^{31}$

Kandungan ayat di atas menunjukkan bahwa manusia adalah makhluk termulia di antara makhluk-makhluk Allah Swt., yang lain. Peniupan ruh dalam ayat di atas dapat juga diartikan dengan sifatsifat Allah Swt., yang mulia juga ditiupkan pada manusia, sehingga sifat-sifat yang mulia telah tertanam pada diri mansusia sejak pertama kali manusia diciptakan oleh Allah Swt., maka dikatakanlah dalam alQur'an bahwa manusia adalah makluk yang diciptakan dengan sebaik-baiknya penciptaan, sebagaimana firman Allah Swt., dalam alQur' an Surah at-Tin (95): 4, Allah Swt., berfirman:

$$
\text { كَقَلْ خَلَقْنَا الْإِنْسَانَ فِنْ أَحْسَنِ تَقْوِيْمِ }
$$

\footnotetext{
${ }^{31}$ QS. As-Sajadah (32): 9.
} 
Hukum Bisnis Perspektif Islam dan Kapitalis

(Tinjauan Teoritis Pada Aktivitas Bisnis di Indonesia)

Artinya: Sesungguhnya kami telah menciptakan manusia dalam bentuk yang sebaik-baiknya. 32

Ayat di atas membuktikan bahwa manusia bukanlah makhluk yang diciptakan dengan sifat-sifat yang tidak terpuji sebagaimana pandangan teori ekonomi konvensional yang berasumsi bahwa manusia adalah makhluk ekonomi (homo economicus) yang serakah dan lebih mementingkan diri sendiri dari pada kepentingan umum. Sekalipun sebagian manusia ada yang bersifat demikian, maka itu disebabkan oleh pengaruh lingkungan dan orang-orang tempat ia tinggal, karena pada dasarnya setiap manusia dilahirkan dalam keadaan fitrah, selanjutnya adalah tergantung bagaimana cara kedua orang tuanya mendidik dan membesarkannya.

Berdasarkan uraian di atas, aktivitas bisnis perspektif Islam tidak memiliki haluan yang sama dengan aktivitas bisnis perspektif kapitalis. Maka perbandingan antara aktivitas bisnis perspekti Islam dan kapitalis memiliki sebuah perbedaan yang sangat signifikan. Perbedaan sebagaimana dimaksud di atas dapat dipetakan ke dalam tiga aspek, yaitu meliputi perbedaan dalam visi, sistem, dan misi atau dalam pengaplikasiannya.

Aktivitas bisnis perspektif Islam merupakan aktivitas bisnis yang memandang manusia sebagai kholifah di muka bumi yang dibekali oleh Allah Swt., sebuah kemampuan untuk mengelola bumi seoptimal mungkin untuk kesejahteraan bersama. Pandangan Islam mengenai hal ini kemudian dikemas dalam sebuah visi homo Islamicus atau perilaku manusia yang berakhlak mulia. Hal ini tentu bertolak dengan aktivitas bisnis kapitalis yang memandang manusia sebagai makhluk yang mementingkan diri sendiri dan terkemas dalam sebuah visi bahwa manusia adalah makhluk ekonomi atau homo economicus.

Berdasarkan visi dari masing-masing aktivitas bisnis sebagaimana dimaksud di atas, maka lahirlah sebuah sistem ekonomi Islam dan sistem ekonomi kapitalis. Islam lebih mengedepankan keseimbangan dalam sistem ekonominya. Jiwa tatanan dalam Islam adalah keseimbangan yang adil. Hal ini terlihat jelas pada hak individu dan hak masyarakat umum. Sebuah sistem ekonomi yang moderat tidak akan pernah mendzolimi masyarakat, khususnya

${ }^{32}$ QS. At-Tin (95): 4. 
kalangan masyarakat yang lemah sebagaimana yang terjadi pada masyarakat kapitalis. ${ }^{33}$

Selain itu, dengan konsep keseimbangan yang adil dalam sistem ekonomi Islam, maka harta kekayaan tidak akan hanya beredar di kalangan orang-orang yang kaya saja, namun harta kekayaan di kalangan orang-orang kaya tersebut akan beredar lebih luas hingga tersalurkan ke kalangan masyarakat yang keadaan ekonominya menengah ke bawah.

Terselenggara perputaran harta kekayaan secara merata sebagaimana dimaksud di atas menunjukkan tercapainya cita-cita dari pada sistem ekonomi Islam itu sendiri, yaitu sebuah perputaran harta kekayaan secara merata baik itu di kalangan orang kaya maupun kalangan masyarakat menengah ke bawah. Hal ini sesuai dengan firman Allah dalam al-Qur'an Surah al-Hashr (59): 7:

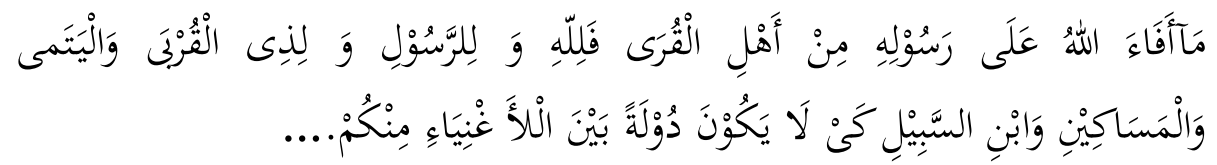

Artinya: Apa saja harta rampasan (fai-i) yang diberikan Allah kepada Rasul-Nya yang berasal dari penduduk kota-kota maka adalah untuk Allah, Rasul, kerabat, Rasul, anak-anak yatim, orang-orang miskin dan orang-orang yang dalam perjalanan, supaya harta itu jangan hanya beredar di antara orang-orang kaya saja di antara kamu. ${ }^{34}$

Sebuah sistem ekonomi akan berdampak pada pengaplikasiannya di tengah-tengah masyarakat. Aplikasi dari sistem ekonomi Islam yang diterapkan dalam aktivitas bisnis di masyarakat cenderung menilai bahwa nilai ekonomi adalah waktu (Economic Value of Time). Cara pengaplikasian sistem ekonomi Islam sangat bertolak dengan sistem ekonomi kapitalis yang lebih memandang uang adalah segalanya, ini menunjukkan bahwa sistem ekonomi kapitalis cenderung menempatkan uang di atas segalanya dan nilai waktu bagi mereka adalah uang (Time Value of Money).

\footnotetext{
${ }^{33}$ Yusuf Al-Qaradhawi, Norma Dan Etika Ekonomi Islam (Jakarta: Gema Insani Press, 1997), 71.

${ }^{34}$ QS. Al-Hashr (59): 7.
} 
Hukum Bisnis Perspektif Islam dan Kapitalis

(Tinjauan Teoritis Pada Aktivitas Bisnis di Indonesia)

Secara ringkas, perbandingan antara aktivitas bisnis perspektif Islam dan aktivitas bisnis perspektif kapitalis dapat disederhanakan dalam tabel berikut ini:

Tabel 1: Perbandingan Aktivitas Bisnis Perspektif Islam Dan Kapitalis

\begin{tabular}{|c|c|c|c|}
\hline No. & Kategori & $\begin{array}{l}\text { Aktivitas Bisnis } \\
\text { Islam }\end{array}$ & $\begin{array}{c}\text { Aktivitas Bisnis } \\
\text { Kapitalis }\end{array}$ \\
\hline 1 & Visi & Homo Islamicus & Homo Economicus \\
\hline 2 & Sistem & $\begin{array}{c}\text { Memberikan } \\
\text { keseimbangan } \\
\text { antara individu, } \\
\text { masyarakat, dan } \\
\text { negara }\end{array}$ & $\begin{array}{c}\text { Meraih keuntungan } \\
\text { yang sebesar-besarnya } \\
\text { dengan modal yang } \\
\text { kecil }\end{array}$ \\
\hline 3 & Aplikasi & $\begin{array}{c}\text { Economic Value of } \\
\text { Time }\end{array}$ & Time Value of Money \\
\hline $\begin{array}{l}\text { relev } \\
\text { seca } \\
\text { men } \\
\text { sesar } \\
\text { oran } \\
\text { mas } \\
\text { men } \\
\text { pera } \\
\text { Und } \\
\text { Syar } \\
\text { baka } \\
\text { lemb } \\
\text { bida }\end{array}$ & $\begin{array}{l}\text { mater: Diol } \\
\text { bersan } \\
\text { Berdasarkan } \\
\text { jika diaplil } \\
\text { kultur c } \\
\text { ngsong ting } \\
\text { supaya ha } \\
\text { orang yang } \\
\text { rakat yang } \\
\text { rong perekc } \\
\text { Hal di atas } \\
\text { ran perunda } \\
\text { g-Undang } \\
\text { n, Undang-L } \\
\text { gelimpahan } \\
\text { ya Pengadi } \\
\text { ekonomi }\end{array}$ & $\begin{array}{l}\text { erdasarkan kreasi pen } \\
\text { u-Isu Kontemporer } \\
\text { of. Dr. H. Abd. Salam } \\
\text { haparan di atas, sist } \\
\text { san dalam kegiatan } \\
\text { budaya masyara } \\
\text { radisi gotong royon } \\
\text { sekayaan tidak hany } \\
\text { a saja, namun tersali } \\
\text { nembutuhkan. De } \\
\text { nian Indonesia menja } \\
\text { akin dikuatkan den } \\
\text { undangan di bidang } \\
\text { nor 21 Tahun } 20 \\
\text { ing Nomor } 3 \text { Tahun } \\
\text { enangan absolut per } \\
\text { Agama dan perat } \\
\text { ariah. Hal ini m }\end{array}$ & $\begin{array}{l}\text { S yang bertumpu pada } \\
\text { ukum Bisnis Syariah } \\
\text { rief, M.A. } \\
\text { ekonomi Islam lebih } \\
\text { nsi di Indonesia yang } \\
\text { t Indonesia masih } \\
\text { dan saling menolong } \\
\text { berputar di kalangan } \\
\text { can ke seluruh elemen } \\
\text { an demikian akan } \\
\text { lebih baik. } \\
\text { n diaturnya beberapa } \\
\text { onomi syariah seperti } \\
\text { tentang Perbankan } \\
\text { 06 yang menjadi cikal } \\
\text { ra ekonomi syarah ke } \\
\text { an-peraturan lain di } \\
\text { upakan fakta yang }\end{array}$ \\
\hline
\end{tabular}


menunjukkan bawha eksistensi kegiatan bisnis berdasarkan prinsip syariah di Indonesia semakin maju dan semakin berkembang dari waktu ke waktu.

\section{Penutup}

Aktivitas bisnis dalam Islam lebih mengedepankan pengabdian yang dilakukan seorang hamba sebagai kholifah yang mengelola bumi ini semata-mata hanya untuk Allah Swt., dan manfaatnya dapat dinikmati oleh masyarakat umum, sehingga suatu harta kekayaan tidak hanya berputar di kalangan orang kaya saja, melainkan tersalurkan sampai ke kalangan orang yang membutuhkan. Hal ini tentu sangat berbeda dengan sistem ekonomi kapitalis yang memberikan kebebasan individu untuk berusaha mendapatkan kekayaan sehingga dapat meningkatkan kesejahteraannya sendiri. Kebebasan tersebut mendorong individu melakukan berbagai inovasi ekonomi dan teknologi yang mendorong kemajuan. Namun, kapitalisme membuat pihak yang tidak memiliki posisi tawar (modal) yang sama dengan pihak lain secara struktural tidak akan dapat bekerja dalam pasar, sehingga ia tidak dapat mencapai kemakmuran.

Dengan demikian, maka dapat disimpulkan bahwa perbandingan antara aktivitas bisnis perspektif Islam dengan aktivitas bisnis perspektif kapitalis memiliki perbedaan yang sangat signifikan. Hal ini dapat dilihat dari hasil pemaparan di atas yang menunjukkan bahwa sistem ekonomi Islam lebih membawa kemaslahatan bagi masyarakat umum dari pada menimbun harta untuk kekayaan individu sebagaimana sistem ekonomi kapitalis.

\section{Daftar Pustaka}

Fadllan. "Paradigma Madzhab-Madzhab Ekonomi Islam Dalam Merespon Sistem Ekonomi Konvensional." AL-IHKAM: Jurnal Hukum \& Pranata Sosial 7, no. 1 (2013): 156-77. https://doi.org/10.19105/al-lhkam.v7i1.322.

Abdain. "Peran Sistem Ekonomi Islam Dalam Menanggulangi Tingkat Kesenjangan Sosial." Jurnal Muamalah IV, no. 2 (2014): 15-26.

Adrian Perkasa. Orang-Orang Tionghoa Dan Islam Di Majapahit. Yogyakarta: Ombak, 2012.

Ai Siti Farida. Sistem Ekonomi Indonesia. Bandung: Pustaka Setia, 2011. Amalia, Euis. Sejarah Pemikiran Ekonomi Islam Dari Masa Klasik Hingga

Kontemporer. Jakarta: Pustaka Asatrus, 2005. 
Hukum Bisnis Perspektif Islam dan Kapitalis

(Tinjauan Teoritis Pada Aktivitas Bisnis di Indonesia)

Ghozali, Muhammad, and Yusi Septa Prasetya. "Ribā Dan Ketidakadilan Sistem Ekonomi Kapitalisme, Sebuah Kajian Teoritis." Islamic Economics Journal 3, no. 1 (2017): 93-115. https://doi.org/10.21111/iej.v3i1.1385.

Haneef, Mohamed Aslam. Pemikiran Ekonomi Islam Kontemporer: Analisis Komparatif Terpilih. Edited by Suherman Rosyidi. Jakarta: Rajawali Press, 2010.

Huda, Choirul. "EKONOMI ISLAM DAN KAPITALISME (Merunut Benih Kapitalisme Dalam Ekonomi Islam)." Economica: Jurnal Ekonomi Islam 7, no. 1 (2016): 27-49. https://doi.org/10.21580/economica.2016.7.1.1031.

Irham Rosdyidi. "Reaktualisasi Model Formulasi Norma Hukum Berbasis Asas Kejujuran Konstitusi Kerajaan-Kerajaan Di Nusantara Ke Dalam Undang-Undang Dasar Negara Republik Indonesia Tahun 1945 (Kerajaan Pagarruyung, Kasunanan Surakarta, Kerajaan Bone, Dan Kesultanan Tidore)." Universitas Brawijaya, 2015. http:/ / repository.ub.ac.id/id/eprint/160416.

John M. Echols dan Hassan Shadily. Kamus Inggris Indonesia "An Engslish-Indonesian Dictionary." Jakarta: Gramedia, 2005.

Karim, Adiwarman Azwar. Sejarah Pemikiran Ekonomi Islam. 3rd ed. Jakarta: Rajawali Press, 2004.

M. Umer Chapra. Islam Dan Tantangan Ekonomi: Islamisasi Ekonomi Kontemporer. Surabaya: Risalah Gusti, 1999.

Mahsun Fuad. Hukum Islam Indonesia: Dari Nalar Partisipatoris Hingga Emansipatoris. Yogyakarta: Pelangi Aksara, 2005.

Muhammad Sharif Chaudry. Sistem Ekonomi Islam: Prinsip Dasar. Jakarta: Kencana, 2012.

Novita Lidyana. "Perbandingan Ekonomi Konvensional Dan Ekonomi Islam," n.d.

Parmujianto. “Manajemen Sumber Daya Manusia Dan Mutu Modal Manusia Dalam Perspektif Ekonom Islam." Et-Tijarie 4, no. 1 (2017): 95-104.

Pius A. Partanto dan M. Dahlan Al-Barry. Kamus Ilmiah Populer. Edited by Arkola. Surabaya, 1994.

Rosyidin. "Aktivitas Bisnis Perspektif Islam Dan Kapitalis (Analisa Komparatif Terhadap Aspek Fundamental Ekonomi Islam Dan Kapitalis Dalam Aktivitas Bisnis)." At-Tahdzib 1, no. 2 (2013).

Rustam Dahlan. “Teori Invisible Hand Adam Smith Dalam Perspektif 
Ekonomi Islam." Jurnal Ekonomi 1, no. 1 (2010).

Suharyono dan Niam Sovie. Sistem Ekonomi Indonesia. Banten: Universitas Terbuka, 2014.

Yhosihara Kunio. Kapitalisme Semu Asia Tenggara. Jakarta: LP3ES, 1990.

Yusuf Al-Qaradhawi. Norma Dan Etika Ekonomi Islam. Jakarta: Gema Insani Press, 1997. 